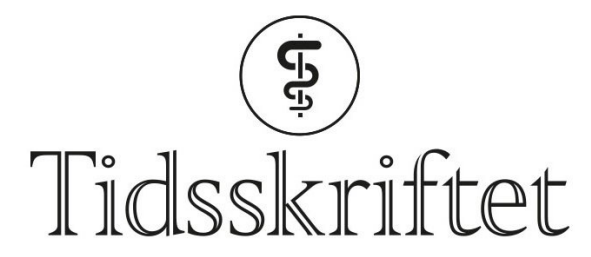

DEN NORSKE LEGEFORENING

\title{
Ikke-invasiv eller invasiv test ved prenatal diagnostikk?
}

FRA ANDRE TIDSSKRIFTER

KETIL SLAGSTAD

Tidsskriftet

Det er fortsatt usikkert om ikke-invasiv prenatal test, såkalt NIPT-test, fører til færre spontanaborter sammenlignet med prøver av fostervann og placenta.

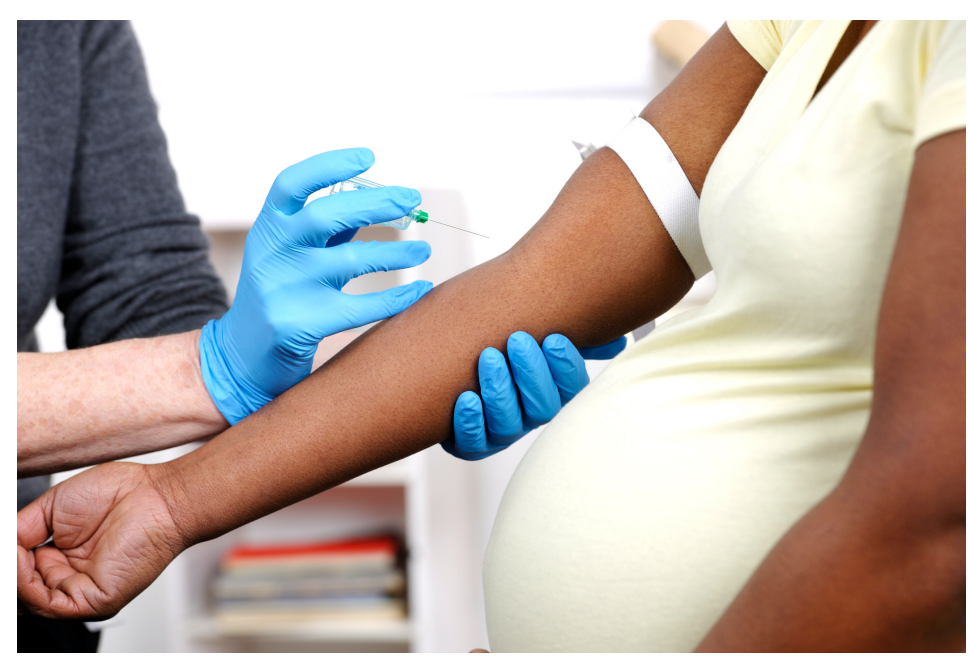

Illustrasjonsfoto: lostinbids/iStock.

I Norge tilbys fosterdiagnostikk til gravide med økt risiko for fosteravvik, i første omgang kombinert ultralydundersøkelse og blodprøve. En ny type blodprøve som sekvenserer cellefritt foster-DNA i mors blod, kan brukes i ikke-invasiv prenatal diagnostikk. Det er vedtatt at testen skal innføres i Norge til bruk som sekundærtest der kombinert ultralydundersøkelse og blodprøve har vist høy risiko for trisomi hos fosteret (1:250 eller høyere). Testen skal tilbys til gravide som et alternativ til invasive prøver, dvs. prøver av fostervann og placenta, og vil trolig kunne tilbys i løpet av høsten 2018. En av grunnene til at den nye testen ble innført, var at den kunne redusere behovet for invasive tester, tester som medfører ubehag og en liten risiko for iatrogen spontanabort.

I en studie som nylig er publisert i tidsskriftet JAMA, ble over 2100 gravide kvinner randomisert til enten ikke-invasiv prenatal test eller invasiv test med kromosomanalyse (1). Kvinnene hadde allerede gjennomgått konvensjonell ultralydundersøkelse og blodprøve, og risikoen for foster med trisomi 21 var over 1:250. Det var ingen forskjell i forekomst av spontanaborter i de to gruppene (o,8 \% i begge grupper). Deteksjonsraten for trisomi 21 for den ikke-invasive testen var $100 \%$ (95\% KI 87,2-100) med en falskt positiv-rate på 5,6\% 
$(4,2-7,2)$, og testen påviste totalt 28 kromosomavvik, hvorav ett ikke var trisomi 21. I gruppen med invasiv testing ble det påvist 49 avvik, hvorav 11 var andre avvik enn trisomi 21. Studien hadde for lav styrke til å påvise en eventuell forskjell i forekomsten av spontanabort.

- I Norge er standard kromosomanalyse erstattet med kopitallsanalyse, sier Torbjørn Eggebø, som er professor ved Norges teknisk-naturvitenskapelige universitet. - Denne studien gir ikke grunnlag for å anbefale kopitallsanalyse som primærtest verken hos kvinner som er over 38 år eller hos kvinner med høy risiko etter kombinert ultralydundersøkelse og blodprøve. Kvinner med negativt resultat på den nye ikke-invasive testen unngår ubehaget forbundet med invasiv testing. Eggebø forteller at blant de 11 ekstra tilfellene av kromosomavvik som ble oppdaget ved kromosomanalyse etter invasiv test, var det fire avvik uten klinisk betydning og fire avvik som kunne oppdages med ultralyd i andre trimester.

- I Danmark kan kvinner med påvist høy risiko for trisomi 21 ved ultralydundersøkelse og blodprøve selv velge mellom den nye ikke-invasive testen og kopitallsanalyse. I Norge bør vi vente på danske erfaringer før vi vurderer å endre anbefalingene. Kopitallsanalyse viser noen ganger funn med usikker klinisk betydning og kan derfor føre til unødvendig bekymring. Avdelingene for medisinsk genetikk og de fostermedisinske sentrene bør utarbeide felles retningslinjer for bruk av kopitallsanalyse, mener Eggebø.

LITTERATUR:

1. Malan V, Bussières L, Winer $\mathrm{N}$ et al. Effect of cell-free DNA screening vs direct invasive diagnosis on miscarriage rates in women with pregnancies at high risk of trisomy 21: A randomized clinical trial. JAMA 2018; 320: 557 - 65. [PubMed][CrossRef]

Publisert: 23. oktober 2018. Tidsskr Nor Legeforen. DOI: 10.4045/tidsskr.18.0662

(C) Tidsskrift for Den norske legeforening 2020. Lastet ned fra tidsskriftet.no 